\title{
A Study on Knowledge, Attitude and Practice in Preventing Transmission of Scabies in Pesantren Darul Fatwa, Jatinangor
}

\author{
Mahirah Binti Mohd Yusof ${ }^{1}$, Silvita Fitri R ${ }^{2}$, Yunita Damopolii ${ }^{3}$ \\ ${ }^{1}$ Faculty of Medicine, Universitas Padjadjaran, ${ }^{2}$ Department of Parasitology, Faculty of Medicine, \\ Universitas Padjadjaran, ${ }^{3}$ Department of Dermatology and Venereology, Faculty of Medicine, \\ Universitas Padjadjaran/Dr. Hasan Sadikin General Hospital Bandung
}

\begin{abstract}
Background: Scabies is caused by infestation and sensitization of Sarcoptess cabiei and is an endemic in tropical and subtropical regions around the world. Several factors in the disease transmission are overcrowded living conditions, poor personal hygiene, unhealthy behaviors and population density. Pesantren is a spesific name for an educational Islamic institution in Indonesia and which w could be one of the risk factors of the transmission the disease. Most of the students (santri) are staying at the institution for a long time. The objective of this study was to know the level of knowledge, attitude and practice of santri in preventing scabies.

Methods: A descriptive study was conducted on 45 santri in Pesantren Darul Fatwa in Jatinangor during September-December 2012. A questionnaire was set up consisting of questions about age, sex, basic knowledge, attitude, and practice of preventing the transmission of scabies. Data were analyzed using frequency distribution.

Results: The level of knowledge and attitude of the respondents to prevent the transmission of scabies were good, meanwhile the level of practice was moderate. There were still questions that could not be answer by the respondents those were the etiology (31.1\%), the cut off chain of transmission (40\%), and how to prevent scabies (37.8\%). Not washing the towel, changing the bed linen and pillow case every 2 weeks were the less good practice performed by the respondents.

Conclusions: The knowledge and attitude towards the prevention of transmission of scabies are good while the practices are moderate. A further study with more sample size should be carried out including enviromental assessment.
\end{abstract}

Key words: Attitude, knowledge, practice, scabies

\section{Introduction}

Scabies is a skin disease caused by infestation and sensitization to Sarcoptess cabiei mites and is an endemic in tropical and subtropical areas such as Egypt, Central and South America, Africa, India, and Southeast Asia. ${ }^{1}$ According to a World Health Organization (WHO) report scabies has a potential to bring about an epidemic condition in an area. This condition was found among others in Bangladesh where children under-6-year-old were affected within a period of 12 months, India (13\%), Australian Aboriginal communities (50\%) and in Sierra Leone $(86 \%){ }^{2}$ Incidence in Indonesia was $4.60-12.95 \%$ in 2002 and was in the thirdranking of the other 12 common diseases. ${ }^{3}$

Scabies occurs mostly to very young, and older children, also young adults,because they are more vulnerable to many skin diseases and reflect reduced immunity. ${ }^{1,2}$ Scabies often occur to children living in boarding schools as they live together with a group of people which will lead to an easy and high risk condition for contracting various contagious diseases especially skin diseases. ${ }^{4}$ Scabies also most often is a result from unhealthy behaviors, such as hanging clothes in the room, exchanged clothes and personal items and also sharing bedding. The transmission of scabies can be divided into two: direct contact (skin to skin) such as by shaking hands, sleeping together and sexual relations, and indirect contact are such as sharing things like clothes, sheets, towels and others. ${ }^{3}$ Several factors that also play a role in disease transmission are low socioeconomic conditions, poor personal 
and environmental hygiene, unhealthy behavior and population density. ${ }^{4}$ The lack of knowledge about personal hygiene affects the increased number of incidence of scabies 15\% due to rarely taking a shower, and $42 \%$ due to frequently sharing clothes with friends. ${ }^{5}$

According to Bloom's theory in Notoatmodjo6, behavior includes knowledge, attitude and practice of an individual. Knowledge is a cognitive domain and is the result of knowing people's sense of any particular object which is important for the formation of a person's actions (overt behavior). Meanwhile, attitude is a readiness or willingness to act, and not an implementation of a particular motive.

Pesantren or Pondok Pesantren is a spesific name for an educational Islamic institution in Indonesia, and throughout the Malay region ${ }^{7}$. This institution is not only the center for Islamic studies but also for the spreading of Islam. ${ }^{7}$ During the day, students attend formal school like any other students outside of pesantren, and in the late afternoon and evening they have to attend religious rituals followed by religious studies and group studies to complete their education. Most of the students stay at the institution for a long time according to the regulation of the pesantren.

Due to the unique epidemiology of scabies, pesantren could be one of the risk factors for the transmission of the disease. A study in Kendal8 found that the prevalence was $27 \%$. Another study by Ma'rufi9 in Lamongan, East Java, found the prevalence of scabies among students was high i.e. $64,20 \%$. There are many factors contributing to this high prevalence, among others are the lack of knowledge, attitude and practice among the santri (pesantren students). This study was conducted to know the level of knowledge, attitude and practice of santri in pondok pesantren Darul Fatwa in Jatinangor in efforts to prevent scabies.

\section{Methods}

This study was conducted on 45 santri who studied and lived in Pesntren Darul Fatwa in Jatinangor for at least 2 months, during the period September-December 2012. The exclusion criteria included santri who couldnot complete the full process of data acquisition by a variety of reasons. A questionnaire was set up consisting of questions about age, sex, basic knowledge of scabies such as clinical etiology, symptoms, risk factors, prevention, treatment, attitude, and practice of santri towards scabies in order to prevent scabies in pondok pesantren. This questionnaire was tested to 30 respondents and Cronbach's Alpha was performed. The test showed that coefficient reliability was 0.744 .

The level of knowledge, attitude, and practice was measured using a scoring system as follows: Good : score is $\geq 75 \%$, Moderate : score is $40 \%-74 \%$, and Poor : when the score is $<40 \% .10$. Data were analyzed using frequency distribution.

\section{Results}

Male respondents with a mean age of 15 years old comprised the highest percentage of the respondents (55.6\%).

The level of knowledge of the respondents in the effort to prevent scabies was generally good $(68.9 \%)$, the level of attitude was good $(80.0 \%)$, and the level of practice based on personal hygiene was moderate (60\%) (Table 1).

In general, the majority of respondents could answer all the questions about scabies correctly except for three questions, those were the etiology of scabies (31.1\%), what to do to break the transmission of scabies (40\%), and how to prevent scabies (37.8\%)

According to Table 3, 28 respondents $(62.2 \%)$ answer agree to dry mattress and pillows every week and it showed that the majority of them strongly agree that they should be aware of scabies even though it does not lead to death which comprised about $66.7 \%$ (30 respondents). However, 4 respondents $(8.9 \%)$ showed less agree to the statement that good personal hygiene could keep the body free from scabies.

Majority of the respondents had a good practice of personal hygiene (Table 4). For the questions of how many times the respondents change clothes during the day, mostly answered 2 or 3 times per day with $46.7 \%$ and $44.4 \%$ respectively. Unfortunately, the highest percentage of practices to spread the disease was washing the towel, changing the bed linen and pillow case every 2 weeks. While there, were still $46.7 \%$ of respondents whopractised bed sharing.

\section{Discussions}

According to Notoatmodjo ${ }^{6}$, the level or quality of knowledge can be grouped into 
Table 1 Distribution of respondents based on level of knowledge \& attitude

\begin{tabular}{|c|c|c|}
\hline & $\begin{array}{c}\text { Frequency, } \\
\text { (Total, } \mathrm{n}=45 \text { ) }\end{array}$ & Percentage (\%) \\
\hline \multicolumn{3}{|l|}{ Level of knowledge } \\
\hline Good (score : $\geq 27$ marks) & 31 & 68.9 \\
\hline Moderate (score : $15-26$ marks) & 14 & 31.1 \\
\hline Poor (score : $\leq 14$ marks) & 0 & 0 \\
\hline \multicolumn{3}{|l|}{ Level of attitude } \\
\hline Good (score : $\geq 23$ marks) & 36 & 80.0 \\
\hline Moderate (score : 13-22 marks) & 9 & 20.0 \\
\hline Poor (score : $\leq 12$ marks) & 0 & 0 \\
\hline \multicolumn{3}{|l|}{ Level of practice } \\
\hline \multicolumn{3}{|l|}{ Personal hygiene } \\
\hline Good (score : $\geq 16$ marks) & 17 & 37.8 \\
\hline Moderate (score : 9-15 marks) & 27 & 60.0 \\
\hline Poor (score : $\leq 8$ marks) & 1 & 2.2 \\
\hline \multicolumn{3}{|l|}{ Habits } \\
\hline Good (score : $\geq 16$ marks) & 31 & 68.9 \\
\hline Moderate (score : 9-15 marks) & 14 & 31.1 \\
\hline Poor (score : $\leq 8$ marks) & 0 & 0 \\
\hline
\end{tabular}

6 levels, where each level is a sequence of processes from the lowest to the highest level. The lowest level is knowing which is is defined as memorizing a material. In this stage, it involves recalling the things that have received stimuli before. The second level is called comprehension, the ability to correctly describe the disease of scabies. The third level is application, the ability in applying the knowledge in everyday life. The next levels are analysis, synthesis and evaluation.

In this study, the level of the respondents' knowledge was more than level one. Because most of the respondents could apply the knowledge of preventing the transmission of scabies in daily life activities such as doing good practices of personal hygiene. However, health education should be carried out since there were still respondents who did not know about the etiology, what to do to break the transmission, and how to prevent scabies. Furthermore, there was no Unit Kesehatan Sekolah (UKS ) provided for the santri in the pesantren.

Attitude is the assessment toward the stimulus or objects and in this case it is a matter of health, including illness. Once a person knows the illness, the next process will be to assess or show attitude towards the illness. Therefore, an indicator for the health attitude starts with the knowledge of health itself. The level of attitude of santri towards the scabies disease was good because they had a good knowledge about it. ${ }^{6}$ Unfortunately, there were still $20.0 \%$ of santri under moderate level of attitude even they had a good level of knowledge. This is because the development of attitude is a process that is not only influenced by knowledge but also involves emotional, past experience and the environment of living conditions. ${ }^{11}$

In this study the level of practice of the respondents' personal hygiene and habits were on a moderate and good level respectively. Researchers assume this might be due to the facilities provided and there were good supports surrounding them in order to practice good personal hygiene and habits. Besides that, according to the theory of S- O-R, practice is produced by the stimulus given (knowledge) and the attitude towards it. ${ }^{6}$ It can be proven that when someone has a good knowledge and a good attitude, then it will cause that person to have a good practice 
Table 2 Distribution of Respondents Based on Type of Knowledge

\begin{tabular}{|c|c|c|c|c|}
\hline No & Question about knowledge & Answer & $\begin{array}{l}\text { Frequency } \\
\text { (n) }\end{array}$ & $\begin{array}{l}\text { Percentage } \\
(\%)\end{array}$ \\
\hline \multirow[t]{2}{*}{1} & Have you ever heard of scabies disease & Yes & 28 & 62.2 \\
\hline & & No & 17 & 37.8 \\
\hline \multirow[t]{3}{*}{2} & What is the cause (etiology) & Sarcoptesscabiei & 14 & 31.1 \\
\hline & & Germs & 28 & 62.2 \\
\hline & & The effect of scractching & 3 & 6.7 \\
\hline \multirow[t]{3}{*}{3} & What are the sign and symptoms & $\begin{array}{l}\text { Got small to large spots which are } \\
\text { reddish and wet }\end{array}$ & 35 & 77.8 \\
\hline & & Itching at night and feel the heat & 10 & 22.2 \\
\hline & & with pus & 0 & 0.0 \\
\hline \multirow[t]{3}{*}{4} & Parts of body that are affected & $\begin{array}{l}\text { Between fingers, armpits, waist, } \\
\text { genitals, elbows, and wrists }\end{array}$ & 30 & 66.7 \\
\hline & & Part that is often being covered & 13 & 28.9 \\
\hline & & Mostly at genital area & 2 & 4.4 \\
\hline \multirow[t]{3}{*}{5} & The transmission of scabies disease & $\begin{array}{l}\text { Skin to skin contact and through } \\
\text { clothes, towels, bed linen, and other } \\
\text { things used by the patient }\end{array}$ & 33 & 73.3 \\
\hline & & Through skin contact only & 4 & 8.9 \\
\hline & & Through clothes and bed only & 8 & 17.8 \\
\hline \multirow[t]{3}{*}{6} & Who can suffer from scabies & $\begin{array}{l}\text { All age groups but more common in } \\
\text { teenagers }\end{array}$ & 39 & 86.7 \\
\hline & & Teenagers only & 1 & 2.2 \\
\hline & & Only in certain age groups & 5 & 11.1 \\
\hline \multirow[t]{3}{*}{7} & $\begin{array}{l}\text { Can exchanging clothes with an infected } \\
\text { person spread scabies }\end{array}$ & Yes, can spread & 22 & 48.9 \\
\hline & & When an immunity is low & 17 & 37.8 \\
\hline & & No, cannot be spread & 6 & 13.3 \\
\hline \multirow[t]{2}{*}{8} & Can scabies be harmful to the health of skin & Yes & 37 & 82.2 \\
\hline & & No & 8 & 17.8 \\
\hline \multirow[t]{3}{*}{9} & Does the patient need to be quarantined & No, just need regular treatment & 35 & 77.8 \\
\hline & & Just keep a distance from patient & 7 & 15.6 \\
\hline & & Yes, need to be quarantined & 3 & 6.7 \\
\hline \multirow[t]{3}{*}{10} & $\begin{array}{l}\text { What should we do to break the chain of } \\
\text { scabies disease }\end{array}$ & $\begin{array}{l}\text { Disinfection on clothing, bed linen } \\
\text { and give treatment simultaneously }\end{array}$ & 18 & 40.0 \\
\hline & & $\begin{array}{l}\text { Keep a distance with others when } \\
\text { being infected by Sarcoptess cabiei }\end{array}$ & 6 & 13.3 \\
\hline & & Need regular treatment only & 21 & 46.7 \\
\hline \multirow[t]{2}{*}{11} & $\begin{array}{l}\text { Can drying mattress and pillow prevent } \\
\text { scabies }\end{array}$ & Yes & 27 & 60.0 \\
\hline & & No & 18 & 40.0 \\
\hline \multirow[t]{3}{*}{12} & How to prevent scabies & $\begin{array}{l}\text { Bath } 2 \text { times per day with soap and } \\
\text { prevent direct contact with the } \\
\text { patients }\end{array}$ & 17 & 37.8 \\
\hline & & $\begin{array}{l}\text { Bath } 2 \text { times per day and keep the } \\
\text { cleanliness of clothes }\end{array}$ & 11 & 24.4 \\
\hline & & $\begin{array}{l}\text { Keep clothing, towels and bedding } \\
\text { from being contaminated with } \\
\text { scabies sufferers }\end{array}$ & 17 & 37.8 \\
\hline
\end{tabular}


Mahirah Binti Mohd Yusof, Silvita Fitri R, Yunita Damopolii: A Study on Knowledge, Attitude and Practice in 135 Preventing Transmission of Scabies in Pesantren Darul Fatwa, Jatinangor

Table 3 Distribution of Respondents based on Types of Attitude

\begin{tabular}{|c|c|c|c|c|}
\hline No & Types of attitude & Answer & $\begin{array}{l}\text { Frequency } \\
\text { (n) }\end{array}$ & $\begin{array}{l}\text { Percentage } \\
\quad(\%)\end{array}$ \\
\hline \multirow[t]{3}{*}{1} & Mattresses and pillows are dried every week & Strongly agree & 28 & 62.2 \\
\hline & & Agree & 17 & 37.8 \\
\hline & & Less agree & 14 & 31.1 \\
\hline \multirow[t]{3}{*}{2} & Scabies sufferers have to be quarantined & Strongly agree & 30 & 66.7 \\
\hline & & Agree & 13 & 28.9 \\
\hline & & Less agree & 2 & 4.4 \\
\hline \multirow[t]{3}{*}{3} & $\begin{array}{l}\text { Did not exchange clothes, towels and bedding } \\
\text { with others }\end{array}$ & Strongly agree & 25 & 55.6 \\
\hline & & Agree & 20 & 44.4 \\
\hline & & Less agree & 0 & 0 \\
\hline \multirow[t]{3}{*}{4} & Scabies patients do not need to be avoided & Strongly agree & 15 & 33.3 \\
\hline & & Agree & 22 & 48.9 \\
\hline & & Less agree & 8 & 17.8 \\
\hline \multirow[t]{3}{*}{5} & $\begin{array}{l}\text { Personal hygiene is very necessary to keep the } \\
\text { body free from scabies }\end{array}$ & Strongly agree & 33 & 73.3 \\
\hline & & Agree & 8 & 17.8 \\
\hline & & Less agree & 4 & 8.9 \\
\hline \multirow[t]{3}{*}{6} & $\begin{array}{l}\text { To keep distance from scabies sufferers is } \\
\text { really necessary or needed }\end{array}$ & Strongly agree & 12 & 26.7 \\
\hline & & Agree & 18 & 40.0 \\
\hline & & Less agree & 15 & 33.3 \\
\hline \multirow[t]{3}{*}{7} & $\begin{array}{l}\text { Scabies can be prevented by maintaining a } \\
\text { good personal hygiene }\end{array}$ & Strongly agree & 27 & 60.0 \\
\hline & & Agree & 18 & 40.0 \\
\hline & & Less agree & 0 & 0 \\
\hline \multirow[t]{3}{*}{8} & If found cases of scabies, treatment should be & Strongly agree & 25 & 55.6 \\
\hline & & Agree & 18 & 40.0 \\
\hline & & Less agree & 2 & 4.4 \\
\hline \multirow[t]{3}{*}{9} & $\begin{array}{l}\text { Besides personal hygiene, there must be a } \\
\text { good environment in order to prevent scabies }\end{array}$ & Strongly agree & 35 & 77.8 \\
\hline & & Agree & 10 & 22.2 \\
\hline & & Less agree & 0 & 0 \\
\hline
\end{tabular}

as well. When someone has known or get information about something, he would do and practice it. ${ }^{10}$

However there were 1 respondents who still practiced bad personal hygiene such as washing towel and changing bed linen after 2 weeks or more. The reason was f lack of facilities. The pesantren was not provided with laundry facilities and they had to wash by themselves. Besides that, there was no extra bed sheet available so that they can change it every week, and some of the respondents even did not use bed sheets. Some of the respondents also practised bad habits by borrowing the towel, clothes and often sleep in other person's bed. This might be due to insufficient toiletries owned by respondents and it already became a habit for a santri to sleep int other person's bed as most of them were being influenced by their friend's practice. According to a theory of the WHO, there are 4 factors for a person to have a certain practice or behavior. This 
Table 4 Distribution of respondents based on types of practice

\begin{tabular}{|c|c|c|c|}
\hline Types of practice & Answer & $\begin{array}{c}\text { Frequency } \\
\text { (n) }\end{array}$ & $\begin{array}{c}\text { Percentage } \\
(\%)\end{array}$ \\
\hline \multirow[t]{21}{*}{ Personal hygiene } & Change clothes $3 \mathrm{x}$ & 20 & 44.4 \\
\hline & Change clothes $2 \mathrm{x}$ & 21 & 46.7 \\
\hline & Change clothes $1 \mathrm{x}$ & 4 & 8.9 \\
\hline & Bath $3 x$ & 3 & 6.7 \\
\hline & Bath $2 x$ & 41 & 91.1 \\
\hline & Bath $1 \mathrm{x}$ & 1 & 2.2 \\
\hline & Wash towel once a week & 14 & 31.1 \\
\hline & Wash towel every 2 weeks & 19 & 42.2 \\
\hline & Wash towel $>2$ weeks & 12 & 26.7 \\
\hline & Change bed linen $<1$ week & 12 & 26.7 \\
\hline & Change bed linen every 2 weeks & 22 & 48.9 \\
\hline & Change bed linen $>2$ weeks & 11 & 24.4 \\
\hline & Change pillowcase every week & 16 & 36.6 \\
\hline & Change pillowcase every 2 weeks & 22 & 48.9 \\
\hline & Change pillowcase $>2$ weeks & 7 & 15.6 \\
\hline & Drying mattress once a week & 11 & 24.4 \\
\hline & Drying mattress every 2 weeks & 17 & 37.8 \\
\hline & Drying mattress once a month & 17 & 37.8 \\
\hline & Drying pillow every week & 14 & 31.1 \\
\hline & Drying pillow for every 2 weeks & 16 & 35.6 \\
\hline & Drying pillow once a month & 15 & 33.3 \\
\hline \multirow[t]{21}{*}{ Habits } & Never borrow a friend's towel & 24 & 53.3 \\
\hline & Rarely borrow a friend's towel & 17 & 37.8 \\
\hline & Often borrow a friend's towel & 4 & 8.9 \\
\hline & Towel never being borrowed by friend & 19 & 42.2 \\
\hline & Towel rarely borrowed by friend & 19 & 42.2 \\
\hline & Towel often borrowed by friend & 7 & 15.6 \\
\hline & Never sharing clothes with friends & 21 & 46.7 \\
\hline & Rarely sharing clothes & 22 & 48.9 \\
\hline & Often sharing clothes & 2 & 4.4 \\
\hline & Clothes never being borrowed by friend & 16 & 35.6 \\
\hline & Clothes rarely borrowed by friend & 24 & 53.3 \\
\hline & Clothes often borrowed by friend & 5 & 11.1 \\
\hline & Never sleep in other's bed & 18 & 40.0 \\
\hline & Rarely sleep in other's bed & 21 & 46.7 \\
\hline & Often sleep in other's bed & 6 & 13.3 \\
\hline & Friends never sleep in your bed & 6 & 13.3 \\
\hline & Friends rarely sleep int your bed & 30 & 66.7 \\
\hline & Friends often sleep in your bed & 9 & 20.0 \\
\hline & Often drying towel after use & 22 & 48.9 \\
\hline & Rarely drying towel after use & 17 & 37.8 \\
\hline & Never drying towel after use & 6 & 13.3 \\
\hline
\end{tabular}


includes thought and feelings like knowledge, perception, attitude and belief, and other 3 factors are personal reference, resources (facilities) and culture. ${ }^{6}$

A small sample size could be one of the limitations in this study. Another limitation was the possibility of bias data influenced by the relactance to answer questions related to the bad image of the pesantren.

This study concluded that the knowledge and attitude towards the prevention of transmission of scabies were good while the practices were moderate. A further study with more sample size should be performed including an enviromental assessment.

\section{References}

1. Walton SF, Currie BJ. Problems in diagnosing scabies, a global disease in human and animal populations. Clin Microbiol Rev. 2007;20(2):268-79.

2. Feldmeier H, Heukelbach J. Epidermal parasitic skin diseases: a neglected category of poverty-associated plagues. Bull World Health Organ. 2009;87:152-9.

3. Djuanda A, Djuanda S, Hamzah M, Aisah S. Ilmu penyakit kulit dan kelamin. 4th ed. Jakarta: Badan Penerbit FKUI; 2005. p. 122-125

4. Saad S. Pengaruh faktor higiene perorangan terhadap angka kejadian skabies di pondok pesantren An-Najach Magelang [dissertation]. Semarang: Diponegoro University; 2008.

5. Kumalasari R. Hubungan tingkat pengetahuan dengan timbulnya kejadian skabies di Pondok Pesantren Modern Islam (PPMI) Assalam Sukoharjo [dissertation]. Surakarta: Universitas Muhammadiyah; 2011.

6. Notoatmodjo PDS. Pendidikan dan perilaku kesehatan. Jakarta: Rineka Cipta. 2003. p. 114-128

7. Zakaria GAN. Pondok pesantren: changes and its future. Journal of Islamic and Arabic Education. 2010;2(2):45-52.

8. Megawati R, Santosa B, Sumanto D. Gambaran kejadian penyakit scabies di Ponpes Al Itqon Di Patebon Kendal. Jurnal Litbang Universitas Muhammadiyah Semarang. 2005;5(2):18-22

9. Ma'rufi I, Keman K, Notobroto HB. Faktor sanitasi lingkungan yang berperan terhadap prevalensi penyakit scabies: studi pada santri di pondok pesantren Kabupaten Lamongan. Jurnal Kesehatan Lingkungan. 2005;2(1):11-8

10. Muzakir. Faktor yang berhubungan dengan kejadian penyakit skabies pada pesantren di Kabupaten Aceh Besar Tahun 2007 [thesis]. Medan: Universitas Sumatera Utara; 2008

11. Andayani LS. Perilaku santri dalam upaya pencegahan penyakit skabies di pondok pesantren Ulumu Qur'an Stabat. USU Institutional Repository. 2005;9(2):172-7. 